\title{
Lithuania's Export Specialization According to Technological Classification
}

\author{
Asta Saboniene, Assoc.Prof. Dr. \\ Department of Economics and International Trade \\ Kaunas University of Technology, Lithuania \\ Email: asta.saboniene@ktu.It \\ Ruta Masteikiene, Dr. \\ Department of Economics and International Trade \\ Kaunas University of Technology, Lithuania \\ Email: ruta.masteikiene@ktu.It \\ Vitalija Venckuviene, Dr. \\ Department of Economics and International Trade \\ Kaunas University of Technology, Lithuania \\ Email: vitalija.venckuviene@ktu.It
}

\section{Doi:10.5901/mjss.2013.v4n11p346}

\section{Abstract}

In the period of the last decade, Lithuanian economy has undergone numerous structural changes concerning manufacturing and exports. This research study introduces the pattern of Lithuania's export specialization according to technological classification and analyses the changes of trade-based indices over the period of $2006-2011$. The evaluation of export specialization lays the foundations to the analysis of actual performance of the manufacturing industry, the current exports structure and forecast the trends of transformation into relatively technological intensive and high-skill labour intensive areas. The core aim of the research paper is to reveal the peculiarities of export specialization according to technological classification of commodities of Lithuanian manufacturing industry. It is significant to reveal the importance not only of the hightech, but also of the low-tech manufacturing industries for the country's economy, whereas these industries prevail in the Lithuanian economic structure. This study employs the revealed comparative advantage approach to examine export specialization pattern and trends in the Lithuanian manufacturing industry according to technological classification at product category level. The study presents calculations of the Balassa, $R C A$ and $\mathrm{XCl}$ indices to illustrate the solutions of the raised scientific problem.

Keywords: export specialization, technological classification, revealed comparative advantage index.

\section{Introduction}

Exports reflect not only the pattern of manufacturing industry specialization and achieved comparative advantage, but make it possible to indirectly evaluate the relative level of factor costs and non-price competitiveness of a country. The growth of Lithuanian economy mostly depends on export demand in international markets, so more attention of researches, business and policy makers is now being played to the analysis of exports results, pattern, development and exports competitiveness. Considering the results of country's economic development, an important task is to evaluate the main changes of export volumes and pattern of export specialization. The rise of costs caused by the increased competition in foreign markets and other problems have impacted the changing trade markets and patterns, the decline of demand of most commodities and the reduction of competitive ability. The specialization changes of Lithuania's exports naturally depend on aspects that are well identified in international trade theory, such as factor of market structure, geographical factors, applied technologies, consumer preferences. The estimation of export specialization according to technological classification is a relevant scientific issue aiming to analyse the actual structure and performance of manufacturing industry, achieved export results and to indicate the competitive commodities demanded by foreign markets. It is actual problem to indicate to what extent has export specialization moved from labour and raw 
material resource intensive goods to high-value added knowledge and technology intensive industries.

The core aim of the research paper is to reveal the peculiarities of export specialization according to technological classification of commodities of Lithuanian manufacturing industry. This paper presents the Lithuanian export specialization indices in the period of 2006-2011 in order to indicate the main changes in comparison with previous periods. The methods of the scientific research employed in this study are scientific analysis and summarizing of literature, mathematic calculations, the comparative analysis of statistical indexes.

\section{The theoretical issues and the methodology}

This research paper uses revealed comparative advantage approach to examine the export specialization pattern and trends in Lithuanian manufacturing according to technological classification of produced commodities. This approach assumes that observed exports patterns reflect the international differences in price and non-price factors. The intent is to provide a deeper understanding concerning the export specialization tendency.

The trade theory suggests several methods to evaluate the trade specialization in a given country. Most of methods aiming at identification of the comparative advantages, revealed past trade data. While considering the changes in industry structure, the most common approach is to evaluate the degree of specialization of a country, or region in trade of output generated within a particular industry. This approach could be applied by considering shares of merchandise exports and imports.

The methods solely based on trade flows could be divided in two groups: the first group of indices use export data; the second group of indices use both export and import data. The best known and widely used indicator to evaluate the export specialization in the first group is the Balassa index, also known as the Revealed Comparative Advantage index. Balassa (1965) outlined that the usage of export and import values of the imported intermediate goods, used for manufacturing of export commodities, can take useful information for evaluating the comparative advantages of a country. The Balassa index is calculated by the product's share in the country's exports in relation to its share in the world trade. This study employs this index, which is calculated in the following way:

$B_{i}^{A}=\left(x_{i}^{A} / X^{A}\right) /\left(x_{i}^{W} / X^{W}\right)$

Where:

$x_{i}^{A}$ - country A exports of product $i$;

$X^{A}-$ total exports of country $A$;

$\mathrm{x}_{\mathrm{i}}^{\mathrm{W}}-$ world exports of product $\mathrm{i}$;

$X^{w}$ - total world exports.

Several modified indicators are presented in modern theories to determine the product's comparative share in international trade among other products (Laursen, 1998, Vollrath, 1991). The most applied index in the second group is known as the LFI index, suggested by Lafay (1992). In contrast to the Balassa index, the LFI index takes imports into account in measuring specialization of export and is represented as a modified version of indicators of international trade specialization, and the competitiveness structure of the domestic manufacturing sector, measured by a set of industry and country-specific variables. The modified Revealed Comparative Advantage $(R C A)$ indices (which use export and import data) have been suggested by Donges, Riedel (1977), Mlangeni (2000), Vollrath (1991) and applied in numerous research studies (Amir 2000, Laursen 1998, Lee 1995, Maule 1996, Prasad 2004, Rana 1988, Saboniene 2009, Yeats 1985).

This study also uses the modified RCA index (based on export and import data), calculated as:

$$
R C A=\left(\frac{X_{i}-M_{i}}{X_{i}+M_{i}}-\frac{\sum\left(X_{j}-M_{j}\right)}{\sum\left(X_{j}+M_{j}\right)}\right) * \frac{100}{1-\frac{\sum\left(X_{j}-M_{j}\right)}{\sum\left(X_{j}+M_{j}\right)}}
$$

Where:

$X_{i}-$ country A exports of product $i$;

$\mathrm{M}_{\mathrm{i}}$ - country A imports of product $\mathrm{i}$;

$X_{j}$ - country A exports of all others products except $i(j=1$ to $n$ and $j \neq i)$;

$M_{j}$ - country $A$ imports of all others products except $i(j=1$ to $n$ and $j \neq i)$.

The $R C A$ index indicates the comparative disadvantage when it is between -100 and 0 ; when the value is between 0 and +100 , it illustrates a specialization and comparative advantage. Revealed comparative advantage index determines what commodity groups take the most important part in the export structure and allows evaluate the level of 
import penetration into the domestic market. This index identifies the groups of commodities that compete in international and domestic markets in the most successful way, in comparison with the import and export data of previous periods. This study applies both indices (Balassa and $R C A$ ) to explicitly assess Lithuanian export specialization and to avoid the distortions. The changes in RCA over time reflect the trend in export specialization and the variations relative position of different activities in overall export structure of country, but the absolute value of $R C A$ does not reflect its competitiveness in world markets. This research also uses the export competitiveness index $X C l$, suggested by Jean-Michel (1998) (cited in Amir, 2000) in order to express the ratio of the world share of country $A$ in export of commodity $i$ in period $t$ (the period under review) to its worlds market share in the previous period. If $\mathrm{XCl}$ of a commodity takes value of greater that unit, this points towards rising export competitiveness.

$\left(\mathrm{XCli}^{\mathrm{A}}\right)^{\mathrm{t}}=\left(\mathrm{X}_{\mathrm{i}}^{\mathrm{A}} / \mathrm{X}_{\mathrm{i}}^{\mathrm{W}}\right)^{\mathrm{t}} /\left(\mathrm{x}_{\mathrm{i}}^{\mathrm{A}} / \mathrm{X}_{\mathrm{i}}^{\mathrm{W}}\right)^{\mathrm{t}-1}$

Where:

$\mathrm{t}$ - the period under review;

t-1 - the previous period;

The application of these indexes is based on understanding that Balassa, RCA, XCI indices, despite of their limitations, provide a useful guide to defining comparative advantage and offers a further insight into the competitiveness of a particular commodity or manufacturing industry and the implications for trade. Although these indices don't provide the source of comparative advantage, they reveal the trade patterns that reflect both relative costs and differences in non-price factors.

\section{The results and the research findings}

Recent economic theory presents several classifications of commodity groups according to resources, technology and skill intensiveness. Krause (1984) applied the commodity classification system grouping commodities to four groups: technology intensive, skilled labour intensive, natural resources intensive, unskilled labour intensive. Trade and Development Report (TDR, 2002) classified product groups into six different categories according to the mix of different skill, technology and capital intensities and scale characteristics: primary commodities, labour-intensive and resourcebased manufactures, manufactures with low skill and technology intensity, manufactures with medium skill and technology intensity, manufactures with high skill and technology intensity, unclassified products. This study is based on the technological classification, used by Erlat et al. (2006), who classified produced commodities to difficult-to-imitate research-intensive goods, easy-to-imitate research-intensive goods, capital-intensive goods, raw material-intensive goods and labour-intensive goods.

The Lithuania's manufacturing industry after its transformational period of two decades mostly consists of low-tech industries (the share of low-tech exceeds 70 per cent in industrial structure). As the state's industry development level is usually evaluated by the structure of manufacturing industry with particular emphasis on high-tech industries, Lithuania's high-tech is quite small as well as medium-high-tech and has comparatively narrow specialization. The long-term variation of Lithuanian manufacturing industry structure in accordance with the level of technological developments has revealed that the low-tech and the medium-low-tech industries gradually grow, but the shares of high-tech and mediumhigh-tech industries slowly decrease in general industrial structure. The indicator of labour productivity of Lithuania's manufacturing is relatively lower than in EU old timers. It suggests no surprise that commodities with high Balassa, RCA indicators belong to Lithuania's low-tech and medium-low-tech. It can be stated that the raw-material intensive goods and labour intensive goods prevail in Lithuania's exports pattern. The technological classification of commodities at two-digit level according RCA indices are presented in Table 1.

Table 1. The technological classification of commodities at two-digit level. (sorted according to positive $R C A$ values and Balassa over unit in 2011, XCl in 2011 compared with 2006)

\begin{tabular}{|c|c|c|c|c|}
\hline $\mathrm{CN}$ & Commodity groups & RCA & $\begin{array}{c}\text { Balassa } \\
\text { index }\end{array}$ & $\mathrm{XCl}$ \\
\hline \multicolumn{5}{|c|}{ Difficult-to-imitate research-intensive goods (DIRG) } \\
\hline 39 & Plastics and articles thereof & 24.91 & 1.9 & 1.71 \\
\hline \multicolumn{5}{|c|}{ Easy-to-imitate research-intensive goods (EIRG) } \\
\hline 35 & Albuminoidal substances & 8.23 & 1.6 & 1.5 \\
\hline \multicolumn{5}{|c|}{ Capital-intensive goods (CIG) } \\
\hline 24 & Tobacco and manufactured tobacco substitutes & 37.08 & 5.8 & 1.4 \\
\hline
\end{tabular}




\begin{tabular}{|c|c|c|c|c|}
\hline \multicolumn{5}{|c|}{ Raw material-intensive goods (RMIG) } \\
\hline 31 & Fertilizers & 67.02 & 11.8 & 0.88 \\
\hline 10 & Cereals & 60.94 & 2.0 & 1.3 \\
\hline 11 & Products of the milling industry & 53.92 & 5.1 & 3.5 \\
\hline 04 & Dairy produce & 49.10 & 5.3 & 1.04 \\
\hline 01 & Live animals & 46.87 & 3.2 & 1.36 \\
\hline 12 & Oil seeds and oleaginous fruits & 45.59 & 1.2 & 1.9 \\
\hline 16 & Preparations of meat, fish & 42.38 & 2.5 & 0.88 \\
\hline 23 & Residues and waste from the food industries & 26.78 & 2.8 & 0.8 \\
\hline 02 & Meat and edible meat offal & 12.83 & 1.5 & 1.44 \\
\hline 19 & Preparations of cereals, flour, starch or milk & 8.71 & 1.2 & 1.19 \\
\hline 18 & Cocoa and cocoa preparations & 7.38 & 1.5 & 0.92 \\
\hline 07 & Edible vegetables and certain roots and tubers & 5.89 & 4.0 & 2.21 \\
\hline 21 & Miscellaneous edible preparations & 2.87 & 2.0 & 1.48 \\
\hline 78 & Lead and articles thereof & 1.86 & 1.0 & 1.08 \\
\hline 03 & Fish and crustaceans & 0.48 & 2.0 & 1.94 \\
\hline \multicolumn{5}{|c|}{ Labour intensive goods (LIG) } \\
\hline 94 & Furniture; bedding, mattresses & 72.85 & 4.8 & 1.28 \\
\hline 56 & Wadding, felt and nonwovens & 46.70 & 3.6 & 1.78 \\
\hline 49 & Printed books, newspapers, pictures & 45.35 & 1.3 & 1.62 \\
\hline 43 & Furskins and artificial fur & 44.32 & 3.7 & 1.84 \\
\hline 44 & Wood and articles of wood & 40.85 & 4.8 & 1.45 \\
\hline 62 & $\begin{array}{l}\text { Articles of apparel and clothing accessories, not knitted or } \\
\text { crocheted }\end{array}$ & 36.11 & 1.4 & 0.79 \\
\hline 61 & Articles of apparel and clothing accessories, knitted or crocheted & 29.96 & 1.2 & 1.12 \\
\hline 63 & Other made - up textile articles & 28.48 & 1.8 & 0.9 \\
\hline 96 & Miscellaneous manufactured articles & 21.18 & 1.4 & 1.29 \\
\hline 53 & Other vegetable textile fibres & 14.98 & 8.0 & 0.77 \\
\hline 46 & Manufactures of straw, of esparto & 13.38 & 1.0 & 0.58 \\
\hline 73 & Articles of iron or steel & 4.86 & 1.1 & 1.42 \\
\hline 68 & Articles of stone; plaster, cement, asbestos & 1.67 & 1.5 & 1.04 \\
\hline
\end{tabular}

Source: estimates based on statistical data of International Trade Centre and data of The Department of Statistics to the Government of the Republic of Lithuania.

The significance of low value-added manufacturers, such as, food, textile and clothing, wood and furniture has not been replaced by the strong performance of relatively high-value added manufactures. Aiming to evaluate the changes and trends of commodity groups which prevail in export structure of Lithuania, the calculation of revealed comparative advantage indices during the period of 2006-2011 has been performed (see Table 2).

Table 2. Balassa, RCA indices of commodities at two-digit level, 2006-2011.

\begin{tabular}{lccccccc}
\hline Commodity groups & 2006 & 2007 & 2008 & $\mathbf{2 0 0 9}$ & $\mathbf{2 0 1 0}$ & $\mathbf{2 0 1 1}$ & \\
\hline Fertilizers (31) & & & & & & & \\
Balassa & 18.40 & 19.00 & 14.50 & 13.10 & 10.90 & 11.80 & declined \\
$R C A$ & 72.05 & 77.90 & 74.80 & 69.23 & 62.03 & 67.02 & declined \\
\hline $\begin{array}{l}\text { Cereals (10) } \\
\text { Balassa }\end{array}$ & 2.00 & 2.70 & 3.10 & 3.50 & 2.90 & 2.00 & fluctuated \\
$R C A$ & 58.20 & 65.41 & 67.08 & 86.22 & 74.08 & 60.94 & fluctuated \\
\hline $\begin{array}{l}\text { Dairy produce (04) } \\
\text { Balassa }\end{array}$ & 7.00 & 7.50 & 5.50 & 6.30 & 5.90 & 5.30 & declined \\
RCA & 70.88 & 71.10 & 60.42 & 65.13 & 55.89 & 49.10 & declined \\
\hline Live animals (01) & & & & & & & \\
Balassa & 3.10 & 4.30 & 4.70 & 5.90 & 4.10 & 3.20 & fluctuated \\
$R C A$ & 53.26 & 58.43 & 61.18 & 68.38 & 53.80 & 46.87 & fluctuated \\
\hline $\begin{array}{l}\text { Products of the milling industry (11) } \\
\text { Balassa }\end{array}$ & 1.90 & 4.00 & 3.60 & 4.30 & 4.90 & 5.10 & increased \\
$R C A$ & 14.45 & 44.68 & 58.38 & 60.13 & 58.50 & 53.92 & increased \\
\hline
\end{tabular}




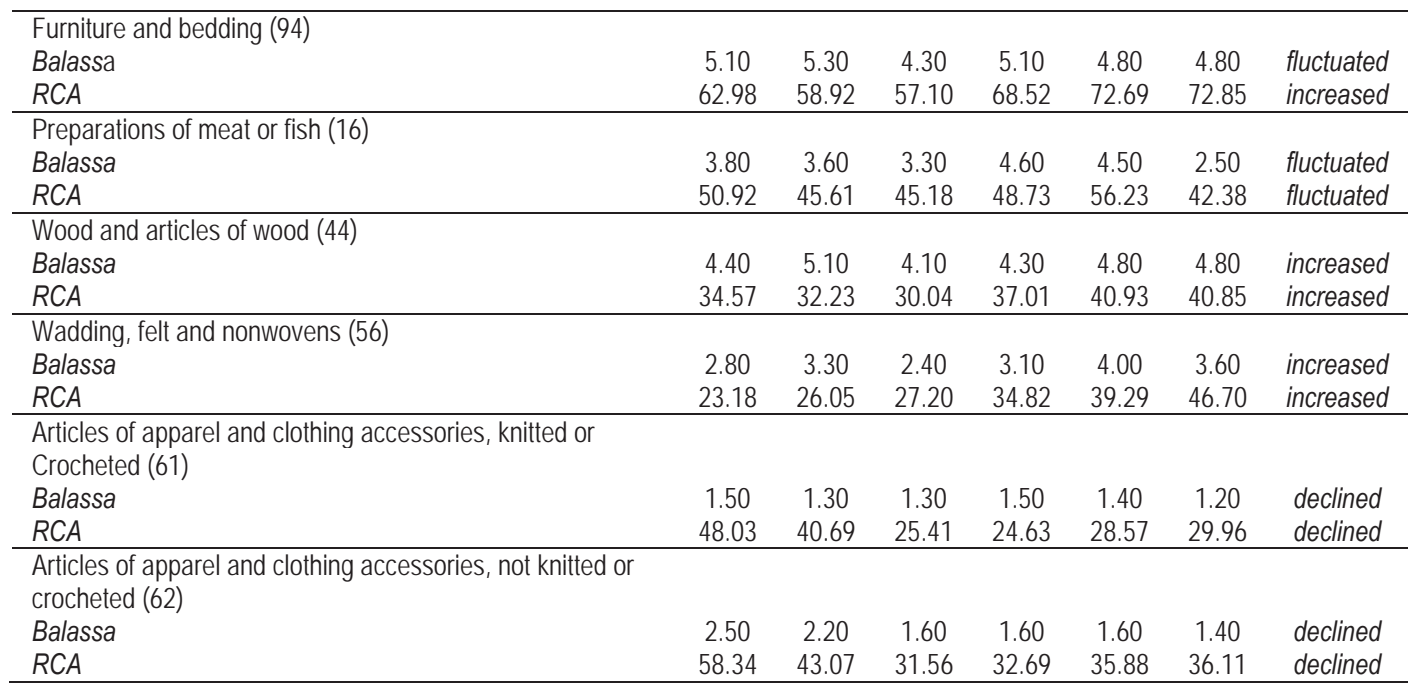

Source: estimates based on statistical data of International Trade Centre and data of The Department of Statistics to the Government of the Republic of Lithuania.

The high trade-based indices belong to commodity groups, which are classified as Raw material-intensive goods - 31 Fertilizers, 10 Cereals, 11 Products of the milling industry, 04 Dairy produce, 01 Live animal and 16 Preparations of meat and fish. The manufacture of chemicals and chemical products holds a relatively large share in industry structure, but only the production of 31 Fertilizers dominate as key export product group. While the Balassa, RCA indices are relatively high, $\mathrm{XCl}$ index (see Table 1) below unit shows the decreasing export share. The declining trend is also confirmed by the decreasing values of the Balassa and RCA indices over the period of 2006-2011.

The Lithuanian food industry is characterized having the largest potential industry in terms of production growth and positive trends. 11 Products of the milling industry has obvious increasing trend over the period studied while other commodity group's indices are relatively high and rotational (see Table 2). In contrary, the indices of 04 Dairy produce gradually decrease, but the $\mathrm{XCl}$ demonstrates a constant export share.

The thirteen groups which are classified as Labour intensive goods have positive RCA and the Balassa index over unit. The study demonstrates the high indices of 94 Furniture and bedding, 44 Wood and articles of wood, 56 Wadding, felt and nonwovens, 53 Other vegetable textile fibres. Lithuania's manufacturing of textiles and wearing apparel is very important in aspects of employment and export. However this low-tech industry is gradually declining. The future performance and potential of this industry requires deeper analysis. On the contrary, wood and furniture manufacturing industries have stable comparative advantage indices and growth of market share. 94 Furniture and bedding, 44 Wood and articles of wood demonstrate increasing indices and growing export shares.

It can be assumed, that only 39 Plastics and articles thereof in Difficult-to-imitate research-intensive group has export specialization (also RCA indices are quite high in 89 Ships, boats and floating structures, but Balassa index is below unit). 35 Albuminoidal substances have relative positive values in the group of Easy-to-imitate research-intensive goods. 24 Tobacco and manufactured tobacco substitutes could be highlighted in the group of Capital-intensive goods.

\section{The concluding remarks}

The transformation of economic system experienced by Lithuanian economy formed the manufacturing industry based on Raw material-intensive goods and Labour-intensive goods. This process has been affected by raw- material and financial sources, labour structure, limited research and innovation activity, rising global competition and variable global demand in the international market. The empirical study of the trade-based indices of manufacturing industry according product's technological classification reveals important insights on the exports pattern and changes of export specialization over the last years. The empirical study confirms the significance of Lithuania's low-tech and reveals the demand of attention for policy makers to analyse the potential not only of the high-tech and medium-high-tech. The 
Lithuania's low-tech and medium-low-tech exports have a vital impact on the countrys' economic growth and exports thus cost-based comparative advantages in these industries should be replaced by non-price factors based on research and innovation activity.

The empirical study has demonstrated the narrow list (the analysis of commodities has been performed on twodigit and four-digit level) of Difficult-to-imitate research-intensive and Easy-to-imitate research-intensive goods as well as Capital-intensive goods. The transformation of Lithuania's exports pattern to high-value added knowledge, high-skill labour intensive and technology intensive industries is a challenge ahead. An attention should be paid to another problem: the decreasing of trade-based indices of commodities with quite good export performance, for example 31 Fertilizers, 04 Dairy produce, 61, 62 Articles of apparel and clothing accessories. The potential possibilities to compete in the international market have been confirmed by dynamics of indices of wood, furniture and food industry. In considering the development of these low-tech industries, very significant aspect for further successful performance is innovation activity and the adoption of higher technologies.

\section{Funding}

This research was funded by a grant (No. IEP-01/2012) from the Research Council of Lithuania.

\section{References}

Amir, M. (2000). Export Specialization and Competitiveness of the Malaysian Manufacturing. Trends, Challenges and Prospects; Conference on International Trade Education and Research, Melbourne.

Balassa, B. (1965). Trade Liberalization and Revealed Comparative Advantage. The Manchester School of Economic and Social Studies, 1965, Vol. 119, 93-123.

Donges, J.B., Riedel, J. (1977). The expansion of manufactured exports in developing countries: An empirical assessment of supply and demand issues. Weltwirtschaftliches Archiv, Band 113: 59-87.

Erlat, G., Erlat, H. (2006). The pattern of Turkish Foreign Trade, 1969-2001. Annual Conference of the MEEA, Boston, USA.

Krause, B. L. (1984). Australia's Comparative Advantage in International Trade in Richard E. Caves and Lawrence B. Krause. The Australian Economy: A View from North, Sydney: George Allen\&Unwin.

Laursen, K. (1998). Revealed Comparative Advantage and the alternatives as Measure of International Specialization, Danish Research Unit for Industrial Dynamics, Working Paper 30, Copenhagen, Denmark.

Lafay, G. (1992). The measurement of revealed comparative advantages. International Trade Modelling, Chapman \& Hall, 209-234.

Lee, J. (1995). Comparative Advantage in Manufacturing as Determinant of Industrialization: The Korean Case. World Development, Vol. 23, No. 7, 1195-1214.

Maule, A. (1996). Some Implications of AFTA for Thailand: A Revealed Comparative Advantage Approach. ASEAN Economic Bulletin, Vol. 13, No 1, 14-38.

Mlangeni, T. (2000). Revealed Comparative Advantage in SADC Economies, South African Update. Trade and Industrial Policy Secretariat (TIPS), Vol. 5.

Prasad, R. N. (2004). Fiji's export competitiveness: a comparison with selected small island developing states. Reserve Bank of Fiji, Working Paper.

Rana, P. B. (1988). Shifting Revealed Comparative Advantage: Experiences of Asian and Pacific Developing Countries, Asian Development Bank, Report No. 42.

Saboniene, A. (2009). Lithuanian Export Competitiveness: Comparison with other Baltic States. Inzinerine Ekonomika-Engineering Economics(2), $49-57$.

Trade and Development Report (TDR) (2002). Annexes to Chapter III. [Online] Available: http://unctad.org/en/Docs/tdr2002ch3a.pdf.

Vollrath, T. L. (1991). A Theoretical Evaluation of Alternative Trade Intensity Measures of Revealed Comparative Advantage. Weltwirtschaftliches Archiv, 130, 265-279.

Yeats, A. J. (1985). On the Appropriate Interpretation of Revealed Comparative Advantage Index: Implications of a Methodology Based on Industry Sector Analysis, Weltwirtschaftliches Archiv. 